\title{
Oil Price Distortion and Their Impact on Algerian Macroeconomic
}

\author{
Cherifa Bouchaour $^{1} \&$ Hussein Ali Al-Zeaud ${ }^{2}$ \\ ${ }^{1}$ Department of Financial Business Economics, Al al-Bayt University, AlMafraq, Jordan \\ ${ }^{2}$ Faculty of Financial and Business Administration, Al al-Bayt University, AlMafraq, Jordan \\ Correspondence: Cherifa Bouchaour, Department of Financial Business Economics, Al al-Bayt University, \\ AlMafraq, Jordan. Tel: 213-697-261-447. E-mail: cherifabouchaour@yahoo.fr
}

Received: June 1, 2012 Accepted: June 29, 2012 Online Published: September 16, 2012

doi:10.5539/ijbm.v7n18p99 URL: http://dx.doi.org/10.5539/ijbm.v7n18p99

\begin{abstract}
The aim of this study is to investigate the impact of Oil Prices distortion on Algerian Macroeconomics during the period (1980 to 2011). Using a Vector Error Correction Model (VECM); the impact of oil price fluctuation on five macroeconomic variables was examined. The results show that Oil Prices have no important Impact on the most variables during the short term with the exception that they have a positive effect on inflation and negative effect on real effective exchange rate. The result of Variance Decomposition analysis VD is consistent with the Impulse Response Function IRF in that there is a Positive Impact in Long-term of Oil Prices on The RGDP and INF. On the other hand; there is a Negative Impact on REER and UNE; with no effect at all on M2.Finally; The Study Recommends the importance of adopting a policy that allows reducing the dependence on the Oil Sector through diversification of income sources which; in turn; helps to raise real GDP; absorb Unemployment in The Local Economy; and reduce Inflationary pressures.
\end{abstract}

Keywords: oil prices fluctuations, RGDP, unemployment, inflation, REER, money supply, vector error correction model, impulse response function, Algeria

\section{Introduction}

Given the strategic importance of oil in the world; and its economic effects vary according to the behavior of prices in the world oil market; which has been in depth fluctuations within the past few decades; especially the rise recorded in July of 2008; where the price per barrel reached \$148 U.S; and the tremors caused by negative or positive effects for many factors mainly: political; economic and natural; which was reflected in the price of oil fluctuation; causing a state of instability; as an oil shock can make the economies of the world cripple; especially the fragile renter economies that related to oil industry.

The everlasting fluctuations of oil price can cause the sharp macroeconomic results; as is usually accompanied by high oil prices in the exporting countries; an increase of the flow of foreign exchange to the national economy that lead to higher income and improve unemployment rates; high exchange rates of the local currency against foreign currencies; coupled with high rates of inflation due to the increase in money supply in the national economy; and is expected the reverse in the case of low prices of oil; but the impact of oil price fluctuations on the economy overall is not that simple; as it constitutes a real challenge for policy makers; economic and financial authorities; thus it was necessary to understand this effects on the economy overall.

Algeria considered one of the oil-producing countries; participating in global production of oil through its company SONATRACH; and its foreign partners about 1.1898 barrels per day in 2010; it export also 709 thousand barrels per day; and estimated oil reserves of 12.2 billion barrels that ranked it the 15th globally. Algeria has become for more than four decades depends on the oil sector, which has become a backbone of the economy; since it has a huge financial returns; as it is the main source of hard currency, and the most important factor to raise the income; for the year 2009; the percentage of oil exports about $98 \%$ of the total exports, nearly $65.5 \%$ of the income tax and is about $31.5 \%$ of GDP; and due to that dependency on oil; the Algerian economy has become vulnerable to oil price fluctuations in the global market; as the continuing rise of prices witnessed since 2003; led to a significant increase in the Gross Domestic Product (GDP) of Algeria; and the increase in GDP growth led to an improvement in the unemployment rates; and increase in inflation as a result of sudden flow of liquidity to the economy.

The aim of this study is to examine the impact of oil prices fluctuations on the Algerian Macro economy during 
the period 1980- 2011; by using five Key macroeconomic variables; real GDP; Unemployment rates; rates of inflation; the effective exchange rate; money supply M2.

\section{Literature Review}

In this section of the study we analysis the research work which was carried out by the different researchers; A number of theoretical studies have examined the impact of oil prices Fluctuations on the Macroeconomic variables; but most researchers focused on the oil-importing countries Sulaiman (2010); investigate the correlation between the oil price variability and export earning with reference to Pakistan for the period of 1975 to 2008. and others focused on the industrialized countries especially the United States of America; where we found a series of studies carried out by Hamilton $(1983 ; 2003 ; 2004 ; 2005 ; 2009)$; in addition to several studies; which focused on the impact of fluctuations in oil prices on macroeconomic variables in the oil-exporting countries such as the study of:

Akin Iwayemi; BabajideFowowe (2011) the study conducts an empirical analysis of the effects of oil price shocks on a developing country oil-exporter (Nigeria). The study found that oil price shocks do not have a major impact on most macroeconomic variables in Nigeria over the period 1985: Q1 to 2007: Q4. The results of the Granger-causality tests, impulse response functions; and variance decomposition analysis all showed that different measures of linear and positive oil shocks have not caused output; government expenditure; inflation; and the real exchange rate. The tests support the existence of asymmetric effects of oil price shocks because we find that negative oil shocks significantly cause output and the real exchange rate.

Gunu Umar (2010) investigated the impact of crude oil price changes on four key macroeconomic variables over the period 1970-2008. By using VAR; the results show that oil prices have significant impact on real GDP; money supply and unemployment. It impact on consumer price index is not significant. This implies that three key macroeconomic variables in Nigeria are significantly explained by exogenous and the highly volatile variable. Hence; the economy is vulnerable to external shocks.

Katsuya Ito (2010) examined the impact of oil prices on the levels of inflation; real effective exchange rate and real GDP for Russia from 1995: Q1 to 2009: Q3; using the VAR model. The result show that the oil prices fluctuations contributes to the growth (decline) in real GDP in the long run. Likewise; the study found that in the short run (4 quarters) rising oil prices not only stimulate inflation and economic growth negatively and positively; respectively; but also induce real effective exchange rate appreciation.

Mohammad Reza Farzanegan; Gunther Markwardt (2009) analyzed the dynamic relationship between oil price shocks and major macroeconomic variables in Iran over the period 1975- 2006 by applying a VAR approach. The study points out the asymmetric effects of oil price shocks; for instance; positive as well as negative oil price shocks significantly increase inflation. And a strong positive relationship between positive oil price changes and industrial output growth. Furthermore; the "Dutch Disease" observed syndrome through significant real effective exchange rate appreciation.

Katsuya Ito (2008) using the VEC model; attempt to empirically investigate the effects of oil price and monetary shocks on the Russian economy over period 1997:Q1 to 2007:Q4. The result shows that an increase in oil prices contributes to real GDP growth, whereas that to inflation. And the monetary shock through interest rate channel immediately affects real GDP and inflation as predicted by theory.

Philip A. Olomola (2006) examined the effect of oil price shock on output; inflation; the real exchange rate and the money supply in Nigeria using quarterly data from 1970 to 2003; using VAR model. The findings were contrary to previous empirical findings in other countries; oil price shock does not affect output and inflation in Nigeria. However; oil price shocks do significantly influence the real exchange rates. The implication is that a high real oil price may give rise to wealth effect that appreciates the real exchange rate. This may squeeze the tradable sector; giving rise to the "Dutch Disease".

Rebeca Jiménez-Rodríguez \& Marcelo Sánchez (2004) assessed empirically the effects of oil price shocks on real economic activities in a sample of seven OECD countries using quarterly data over the period 1972:II-2001:IV. Multivariate VAR analysis is carried out using both linear and non-linear models. They found evidence of a non-linear impact of oil prices on real GDP. In particular; oil price increases are found to have an impact on GDP growth of a larger magnitude than that of oil price increases are found to have a negative impact on economic activity in all cases but Japan. Moreover; the effect of oil shocks on GDP growth differs between the two oil exporting countries in the study sample; with oil price increases affecting the UK negatively and Norway positively. 


\section{Transmission Mechanisms (Channels)}

The oil prices fluctuations affect the performances of macroeconomic variables through six channels; Figure 1 hold the main idea:

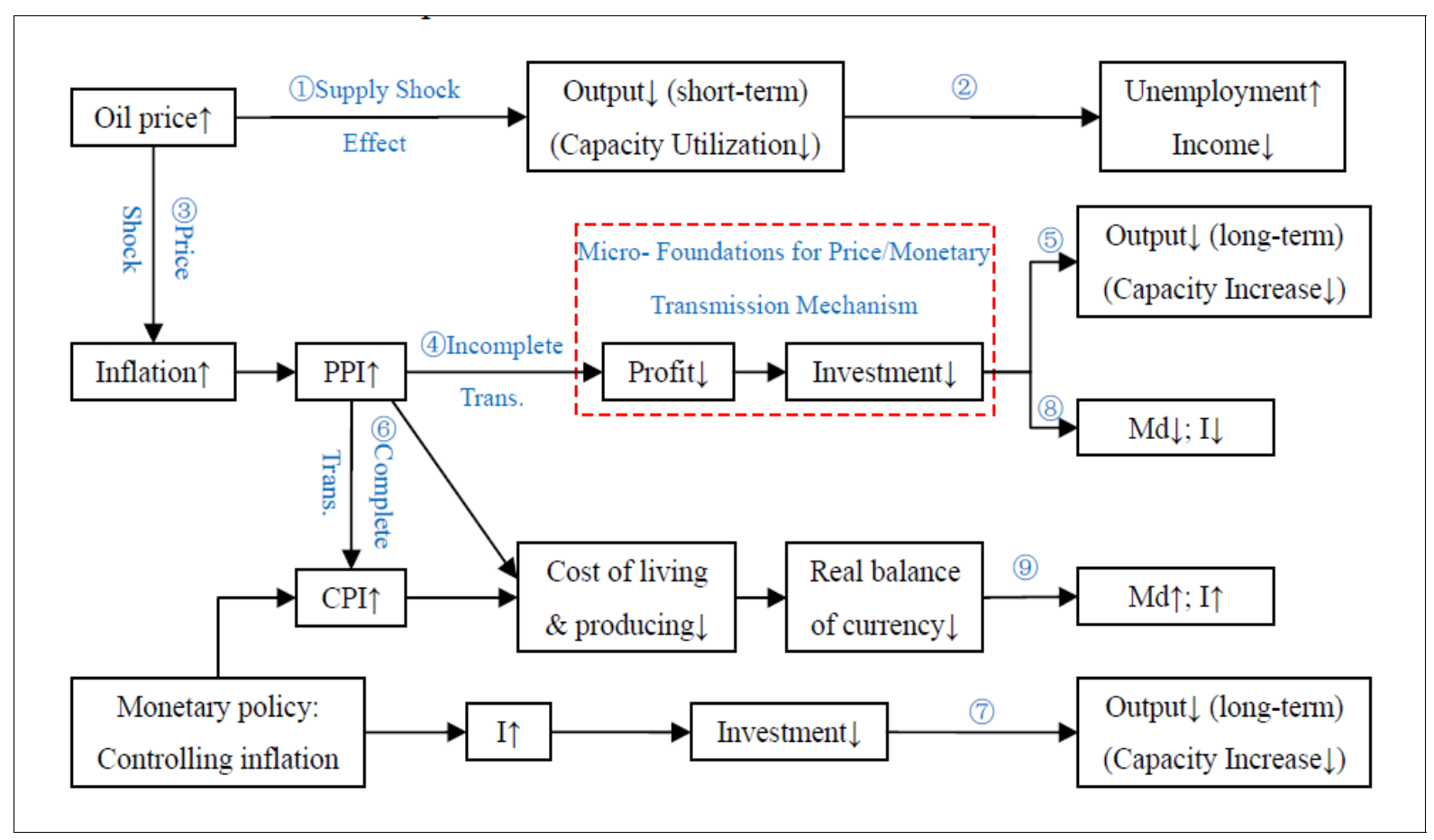

Figure 1. Transmission mechanisms

Source: Chuk, L. Effiong \& Ndifreke (2010).

Figure 1 depicts the channels of transmission from oil price shocks to macroeconomic variables. We briefly discuss these mechanisms below:

- Supply- side shock effect: focusing on the direct impact on output due to the change in marginal producing costs caused by oil-price shock.

- Wealth transfer effect: emphasizing on the different marginal consumption rate of petrodollar and that of ordinary trade surplus.

- Inflation effect: analyzing relationship between domestic inflation and oil prices.

- Real balance effect: investigating the change in money demand and monetary policy.

- Sector adjustment effect: estimating the adjustment cost of industrial structure; which is mainly used to explain the asymmetry in oil-price shock impact.

- Unexpected effect: focusing on the uncertainty about oil price and its impact.

\section{Trend of Oil Prices}

Oil market characterize by since the first oil shock in 1973 which mainly arose as a result of oil embargo of Middle East to countries that support Israel. And oil prices know deep fluctuations. 


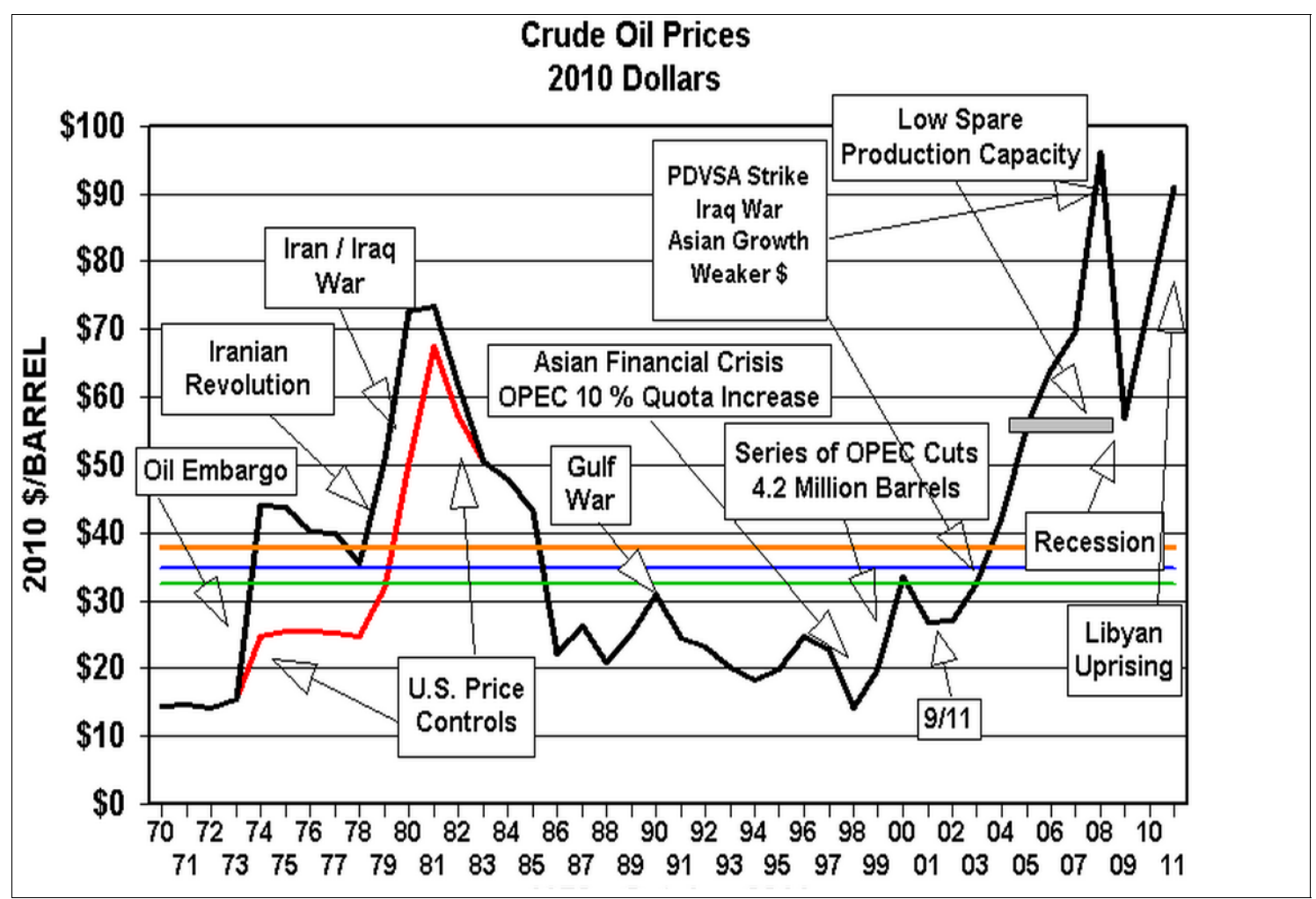

Figure 2. Trend of oil prices since 1970 to 2011

Source: http://www.wtrg.com/oil_graphs/oilprice1970.gif

During the period 1973-1985 the pricing in oil market was controlled by oligopolistic and the OPEC; in 1973 Arab oil embargo backdrop of the support of the Zionist entity; As a result of the Yom Kippur war, crude oil price; quadrupled from $\$ 3$ per bbl in 1972 to $\$ 12$ per bbl by the end of 1974 . Figure 2 show that the revolution in Iran and the subsequent Iran-Iraq war more than doubled prices from $\$ 14$ per bbl in 1978 to $\$ 35$ per bbl in 1981.The crush of 1986: this year know a severe decline in oil prices due to the most of countries members in OPEC don't respect the production quotas; in addition to the role played by countries outside OPEC (KU Britain and Norway) in supply side; on the other hand; lower consumption resulting from rising global prices during the crisis 73 .

During most of the 1990s; crude oil prices fluctuated above $\$ 20$ per barrel. High price volatility is observable in 1990 - 1991 the second Gulf War when the oil prices know a positive shock; that led to increased oil prices because of the Iraq invasion of Kuwait in 1990.But after 1991; oil prices continued to fall; and during the Asian crisis in 1997 and 1998 when oil prices knew a significant decline reached less than 10 \$; this crises occurred because of the Asian recession crisis and increased production of consumer countries. Since the end of 1999 all the raw materials began to know most of the recovery.

Prices fluctuated in the $\$ 25$ to $\$ 30$ range in the first half of 2000 ; and continued to display volatility. Crude oil prices continued to decline in 2001 as global economic activity slowed and with growth prospects dampened. Prices plummeted with the September 11 attack .But in the beginning of 2002 the prices know some of Recovery; due to strong world economic growth which led to strong world oil demand. Main drivers behind growth in oil demand included growth in consumption particularly from China, the US; and the Middle East. In the end of first quarter of 2003 the Oil prices began to record unprecedented and continuous increasing; influenced by the Iraq war as well as unrest in Venezuela. The price of oil rose in 29 of the 40 months between September 2003 and December 2006. The price of curd oil, which averaged only $34 \$$ per barrel in January 2004; rose steadily. During the Israel- Lebanon war of July 2006; oil prices reached $75 \$$ per barrel. Prices fell briefly below $55 \$$ per barrel in January 2007 due to mild winter. In the period 2007/2008 oil prices volatility was characterized by sharp increase in the prices of oil; immediately followed by equally sharp declines.

The global financial crisis 2008: record high of US $\$ 147$ by the July 2008; adding to the global inflationary environment. Worries about how energy prices were affecting the global economy; added to worries about the 
strengthening of the American dollar and declining demand in industrialized nations; and OPEC production cut. These factors as well as continued fears over global recession caused oil prices to plummet; reaching $\$ 43.25$ by mid-December 2008.

2009 characterized by global recession and the declining in world economic output; which led to reduce the demand for oil in many sectors; as a result; oil prices collapse. During the first half of 2011; oil supply was affected by temporary shutdowns of production in countries that are not members of the Organization of Petroleum Exporting Countries (OPEC) for maintenance and capacity expansions and by supply disruptions in Libya.

\section{Methodology and Model Specification:}

The paper makes use of Variance Autoregressive (VAR) Model. Generally a VAR model is specified as:

$$
y_{t}=m+A_{1} y_{t-1}+A_{2} y_{t-2}+\ldots+A_{p} y_{t-p}+\varepsilon_{\mathrm{t}}
$$

Equation (1) specifies VAR (P) process; where $\mathrm{Ai}(\mathrm{i}=1,2 \ldots \mathrm{p})$ are $\mathrm{K} \times \mathrm{K}$ matrices of coefficients; $\mathrm{m}$ is a $\mathrm{K} \mathrm{x}$ 1 vector of constants and $\varepsilon_{t}$ is a vector of white noise process. The easiest way to appreciate the feature of VAR is to specify a simple VAR. Consider a simple VAR where $\mathrm{K}=2$ and $\mathrm{p}=1$. This gives:

$$
\begin{aligned}
\left(\begin{array}{l}
y_{1 t} \\
y_{2 t}
\end{array}\right)=\left(\begin{array}{l}
m_{1} \\
m_{2}
\end{array}\right) & +\left(\begin{array}{ll}
a_{11} & a_{12} \\
a_{21} & a_{22}
\end{array}\right)\left(\begin{array}{l}
y_{1, t-1} \\
y_{2, t-1}
\end{array}\right)+\left(\begin{array}{l}
\varepsilon_{1} \\
\varepsilon_{2}
\end{array}\right) \\
y_{t} & =m+A y_{t-1}+\varepsilon_{t}
\end{aligned}
$$

More explicitly; this can be written as:

$$
\begin{aligned}
& y_{1 t}=m_{1}+a_{11} y_{1, t-1}+a_{12} y_{2, t-1}+\varepsilon_{1 t} \\
& y_{2 t}=m_{2}+a_{22} y_{1, t-1}+a_{22} y_{2, t-1}+\varepsilon_{2 t}
\end{aligned}
$$

Thus; each variable in VAR is expressed as a linear combination of lagged values of itself and lagged values of all other variables in the group. The behavior of the y depend on the properties of the A matrix. If the Eigen values and Eigen vectors of the A matrix are:

$$
\lambda=\left(\begin{array}{cc}
\lambda_{1} & 0 \\
0 & \lambda_{2}
\end{array}\right) \quad \mathrm{C}=\left(\begin{array}{cc}
\vdots & \vdots \\
C_{1} & C_{2} \\
\vdots & \vdots
\end{array}\right)
$$

Provided the Eigen values are distinct; the eigenvectors will be linearly independent and $\mathrm{C}$ will be nonsingular. It then follows that:

Defining a new vector $Z_{\mathrm{t}}$ as:

$$
C^{-1} A C=\lambda \text { and } A=C \lambda C^{-1}
$$

$$
Z_{t}=C^{-1} y_{t} \text { or } y_{t}=C Z_{t}
$$

The process of per-multiplying (2) by $\mathrm{C}^{-1}$ and simplifying gives:

$$
Z_{t}=m^{*}+\lambda Z_{t}+\eta_{t}
$$

Where $\mathrm{m}^{*}=\mathrm{C}^{-1}$ and $\eta_{\mathrm{t}}=\mathrm{C}^{-1} \varepsilon_{t}$

Thus:

$$
\begin{aligned}
& Z 1 t=m^{*} 1+\lambda 1 Z 1, t-1+\eta_{1 \mathrm{t}} \\
& Z 2 t=m^{*} 2+\lambda 2 Z 2, t-1+\eta_{2 \mathrm{t}}
\end{aligned}
$$

Each $\mathrm{Z}$ variable follows a separate $\mathrm{AR}(1)$ process and is stationary $\mathrm{I}(0)$; if the Eigen value has modulus less than1; is a random walk with drift I(1); if the Eigen value is 1; and is explosive; if the eigen value exceeds 1 in numerical value. Finally; it is important to look for the cointegrating relation. Using equation (4) such relation can readily be found. The second bottom row in equation (4) gives:

$$
\mathrm{Z}_{2 \mathrm{t}}=\mathrm{c}(2) \mathrm{y}_{\mathrm{t}}
$$

Where $\mathrm{c}(2)$ is the bottom row in C-1. Thus; $\mathrm{z}_{2}$ is the linear combination of I(1)variables but is itself a stationary $\mathrm{I}(0)$ variable. The cointegrating vector annihilates the $\mathrm{I}(1)$ component in $\mathrm{y}_{\mathrm{t}}$. 
So the VECM is a special form of the VAR for I(1) variables that are co-integrated. The VEC model allows us to capture both the short-run and long-run relationships. For example; we can examine how much GDP will change in response to a change in the other variables (the cointegration part) as well as the speed of change (the error correction part). The direction of Granger causality in the short run and the long run can be determined based on the VECM. The short-run Granger causality can be established by conducting a joint test of the coefficients in the VECM; which is based on the F-test and $\chi^{2}$ test. The long-run causal relationship; on the other hand; is implied through the significance of the lagged error correction term in the VECM; based on the $t$ test.

\section{Data Sources}

The variables used are as follows: real oil price $(O P)$ defined as crude oil prices in real terms; and real GDP $(R G D P)$ defined as GDP at constant price; and Unemployment (UNE) measured as percentage of labor force; inflation rate $(I N F)$ as measured by the percentage changes of consumer price index (CPI; 2005=100); real effective exchange rate (REER2005=100); Money Supply (M2). The data for RGDP; UNE; INF; are obtained from International Monetary Fund IMF from (http://www.economywatch.com/economic-statistics/Algeria); from Federal State Statistics Service (http://www.gks.ru/); oil prices OPEC Annual Statistical Bulletin 2010/2011 and 2005; and the rest from World Bank (http://www.data.worldbank.org). The time span covered by the series is from 1980 to 2011 giving 32 observations. All series were expressed in logarithmic form.

\section{Model Specification}

This paper investigates the impact of oil price shocks on the Algerian Macroeconomic. Following other studies (Hamilton 1983; Mork 1989; Sims 1980; Farzanegan and Markwadt 2009) 5 macroeconomic variables are included in the analysis and these are real GDP (RGDP); Unemployment Rates (UNE); inflation (INF); real effective exchange rate (REER); and Money supply (M2). We make use of Annual data for Algeria over the period 1980 to 2011. The variables and the period of analysis were selected based on the availability of data and all data were obtained from the Central Bank of Algeria. The model for this study is specified as:

$$
\begin{aligned}
& \Delta R G D P_{t}=\sum_{t=1}^{L} \alpha_{11}^{t} \Delta R G D P_{t-1}+\alpha_{12}^{0} \Delta U N E_{t}+\sum_{t=1}^{L} \alpha_{12}^{t} \Delta U N E_{t-1}+\alpha_{13}^{0} \Delta I N F_{t}+\sum_{t=1}^{L} \alpha_{13}^{t} \Delta I N F_{t-1}+\alpha_{14}^{0} \Delta R E E R_{t} \\
& +\sum_{t=1}^{L} \alpha_{14}^{t} \Delta R E E R_{t-1}+\alpha_{15}^{0} \Delta M s_{t}+\sum_{t=1}^{L} \alpha_{15}^{t} \Delta M s_{t-1}+\alpha_{16}^{0} \Delta O P_{t}+\sum_{t=1}^{L} \alpha_{16}^{t} \Delta O P_{t-1}+\varepsilon_{1 t} \\
& \Delta U M E_{t}=\sum_{t=1}^{L} \alpha_{21}^{t} \Delta U M E_{t-1}+\alpha_{22}^{0} \Delta R G D P_{t}+\sum_{t=1}^{L} \alpha_{22}^{t} \Delta R G D P_{t-1}+\alpha_{23}^{0} \Delta I N F_{t}+\sum_{t=1}^{L} \alpha_{23}^{t} \Delta I N F_{t-1}+\alpha_{24}^{0} \Delta R E E R_{t} \\
& +\sum_{t=1}^{L} \alpha_{24}^{t} \Delta R E E R_{t-1}+\alpha_{25}^{0} \Delta M s_{t}+\sum_{t=1}^{L} \alpha_{25}^{t} \Delta M s_{t-1}+\alpha_{26}^{0} \Delta O P_{t}+\sum_{t=1}^{L} \alpha_{26}^{t} \Delta O P_{t-1}+\varepsilon_{2 t} \\
& \Delta I N F_{t}=\sum_{t=1}^{L} \alpha_{31}^{t} \Delta I N F_{t-1}+\alpha_{32}^{0} \Delta R G D P_{t}+\sum_{t=1}^{L} \alpha_{32}^{t} \Delta R G D P_{t-1}+\alpha_{33}^{0} \Delta U M E_{t}+\sum_{t=1}^{L} \alpha_{33}^{t} \Delta U M E_{t-1}+\alpha_{34}^{0} \Delta R E E R_{t} \\
& +\sum_{t=1}^{L} \alpha_{34}^{t} \Delta R E E R_{t-1}+\alpha_{35}^{0} \Delta M s_{t}+\sum_{t=1}^{L} \alpha_{35}^{t} \Delta M s_{t-1}+\alpha_{36}^{0} \Delta O P_{t}+\sum_{t=1}^{L} \alpha_{36}^{t} \Delta O P_{t-1}+\varepsilon_{3 t} \\
& \Delta R E E R_{t}=\sum_{t=1}^{L} \alpha_{41}^{t} \Delta R E E R_{t-1}+\alpha_{42}^{0} \Delta R G D P_{t}+\sum_{t=1}^{L} \alpha_{42}^{t} \Delta R G D P_{t-1}+\alpha_{43}^{0} \Delta U M E_{t}+\sum_{t=1}^{L} \alpha_{43}^{t} \Delta U M E_{t-1}+\alpha_{44}^{0} \Delta I N i \\
& +\sum_{t=1}^{L} \alpha_{44}^{t} \Delta I N F_{t-1}+\alpha_{45}^{0} \Delta M s_{t}+\sum_{t=1}^{L} \alpha_{45}^{t} \Delta M s_{t-1}+\alpha_{46}^{0} \Delta C O P_{t}+\sum_{t=1}^{L} \alpha_{46}^{t} \Delta O P_{t-1}+\varepsilon_{4 t} \\
& \Delta \mathrm{Ms}_{t}=\sum_{t=1}^{L} \alpha_{51}^{t} \Delta M s_{t-1}+\alpha_{52}^{0} \Delta R G D P_{t}+\sum_{t=1}^{L} \alpha_{52}^{t} \Delta R G D P_{t-1}+\alpha_{53}^{0} \Delta U M E_{t}+\sum_{t=1}^{L} \alpha_{53}^{t} \Delta U M E_{t-1}+\alpha_{54}^{0} \Delta I N F_{t} \\
& +\sum_{t=1}^{L} \alpha_{54}^{t} \Delta I N F_{t-1}+\alpha_{55}^{0} \Delta R E E R_{t}+\sum_{t=1}^{L} \alpha_{55}^{t} \Delta R E E R_{t-1}+\alpha_{56}^{0} \Delta O P_{t}+\sum_{t=1}^{L} \alpha_{56}^{t} \Delta O P_{t-1}+\varepsilon_{5 t} \\
& \Delta O P_{t}=\sum_{t=1}^{L} \alpha_{61}^{t} \Delta O P_{t-1}+\alpha_{62}^{0} \Delta R G D P_{t}+\sum_{t=1}^{L} \alpha_{62}^{t} \Delta R G D P_{t-1}+\alpha_{63}^{0} \Delta U M E_{t}+\sum_{t=1}^{L} \alpha_{63}^{t} \Delta U M E_{t-1}+\alpha_{64}^{0} \Delta I N F_{t} \\
& +\sum_{t=1}^{L} \alpha_{64}^{t} \Delta I N F_{t-1}+\alpha_{65}^{0} \Delta R E E R_{t}+\sum_{t=1}^{L} \alpha_{65}^{t} \Delta R E E R_{t-1}+\alpha_{66}^{0} \Delta M s_{t}+\sum_{t=1}^{L} \alpha_{66}^{t} \Delta M s_{t-1}+\varepsilon_{6 t}
\end{aligned}
$$


Where: RGPD is Real Gross Domestic Product; UNE is unemployment; INF is Inflation Rate; M2 is money supply; and OP is Real crude oil prices. $L$ is the lag length; $t$ is time and is vector of innovations. The variables are time series variables and the data is sourced from IFM and OPEC bulletin respectively.

The VAR model is adopted for this study because of the forecasting power relative to large structural models. Again one of the common virtues of VAR is that it obviates a decision as to what contemporaneous variables are exogenous; all variables are endogenous.

\section{Results and Discussion}

\subsection{Unit Root Tests}

Unit root tests for all the variables are presented in Table 1; Both Augmented Dickey- Fuller (ADF) and Phillips - Perron unit root tests are conducted.

Table 1. Unit root test

\begin{tabular}{|c|c|c|c|c|c|c|c|c|c|}
\hline & \multicolumn{4}{|c|}{$\mathrm{ADF}$} & \multicolumn{4}{|c|}{$\mathrm{pp}$} & \multirow{3}{*}{ Decision } \\
\hline & \multicolumn{2}{|c|}{ Levels } & \multicolumn{2}{|c|}{ First difference } & \multicolumn{2}{|c|}{ Levels } & \multicolumn{2}{|c|}{ First difference } & \\
\hline & None & intercept & None & intercept & None & intercept & None & intercept & \\
\hline $\mathrm{OP}$ & -0.03 & -1.15 & $-5.70 * * *$ & $-3.96 * * *$ & -0.03 & -1.13 & $* * *-5.70$ & $* * *-5.60$ & $\mathrm{I}(1)$ \\
\hline RGDP & 5.70 & 0.23 & -1.30 & $-3.96 * * *$ & 4.52 & 0.03 & $-2.27 * *$ & $* * *-4.03$ & $\mathrm{I}(1)$ \\
\hline REER & -1.56 & -0.91 & $-3.90 * * *$ & $-4.10 * * *$ & -1.41 & -0.96 & $* * *-3.93$ & $* * *-4.10$ & $\mathrm{I}(1)$ \\
\hline UNE & -0.53 & -0.92 & $-2.71 * * *$ & $-2.71 * *$ & -0.61 & -0.61 & $-2.65 * * *$ & $-2.66 *$ & $\mathrm{I}(1)$ \\
\hline INF & -1.03 & -2.36 & $-8.13 * * *$ & $-8.02 * * *$ & -1.07 & -2.39 & $-8.01 * * *$ & $-8.01 * * *$ & $\mathrm{I}(1)$ \\
\hline M2 & 10.20 & -0.15 & $-1.61 *$ & $-4.70 * * *$ & 9.13 & -0.12 & $-1.35^{*}$ & $-4.79 * * *$ & $\mathrm{I}(1)$ \\
\hline
\end{tabular}

* Significance at $1 \%$ level. ** Significance at5\%level. *** Significance at $10 \%$ level.

The two tests show similar results that all the six variables of the model are not stationary at level; but they all stationary at first difference I(1). Since the series is integration of same orders we do conduct the co-integration tests.

\subsection{Co-Integration Test}

A vector of variables integrated of order one is cointegrated if there exists linear combination of the variables, which are stationary. Following the approach of Johansen and Juselius (1990) two likelihood ratio test statistics; the maximal Eigen value and the trace statistic; were utilized to determine the number of co-integrating vectors. The co-integration tests were performed allowing for both the presence and absence of linear trends.

Table 2. Co- integration test

\begin{tabular}{lccccc}
\hline \multicolumn{1}{c}{ H } & $\begin{array}{c}\text { Trace } \\
\text { Test Critical } \\
\text { Value 5\% }\end{array}$ & $\begin{array}{c}\text { likelihood } \\
\text { ratio Critical } \\
\text { 5\% Value }\end{array}$ & $\begin{array}{c}\text { Trace } \\
\lambda_{\max }=-T \ln \left(1-\widehat{\lambda_{i}}\right)\end{array}$ & $\begin{array}{c}\text { likelihood ratio } \\
\lambda_{\text {trace }}=-T \sum L n\left(1-\hat{\lambda_{i}}\right)\end{array}$ & $\begin{array}{c}\text { Eigenvalue } \\
\widehat{\lambda_{i}}\end{array}$ \\
\hline $\mathrm{r} \leq 0^{*}$ & 95.75366 & 40.07757 & 140.9888 & 43.72504 & 0.767183 \\
$\mathrm{r} \leq 1^{*}$ & 69.81889 & 33.87687 & 97.26380 & 37.72452 & 0.715631 \\
$\mathrm{r} \leq 2^{*}$ & 47.85613 & 27.58434 & 59.53928 & 34.12038 & 0.679331 \\
$\mathrm{r} \leq 3$ & 29.79707 & 21.13162 & 25.41889 & 12.32552 & 0.336914 \\
$\mathrm{r} \leq 4$ & 15.49471 & 14.26460 & 13.09337 & 7.046105 & 0.209327 \\
$\mathrm{r} \leq 5^{*}$ & 3.841466 & 3.841466 & 6.047264 & 6.047264 & 0.182558 \\
\hline
\end{tabular}

Trace Max-eigenvalue test indicates 3 cointegratingeqn(s) at the 0.05 level

* denotes rejection of the hypothesis at the 0.05 level

**MacKinnon-Haug-Michelis (1999) p-values 
The finding of Johansen co integration shows in table 2. The result of the maximal Eigen values and trace test statistics for the model shows that the variables are co integrated at $r=3$. There are tree long run co integrated equations in vector six. Optimal lag of VAR (Vector Autoregressive) structure model is 2 lag by using Akika Criterion and Shewariz criterion. So the finding shows that there is a long run association among the variables.

\subsection{Granger-Causality Tests}

The Granger-causality tests show the direction of co-integrated relation; results are presented in Table 3; and it can be seen that for RGDP; UNE; INF; REER and M2.

Table 3. Granger causality

\begin{tabular}{lcc}
\hline Null Hypothesis: & p-value & Test F \\
\hline RGDP does not Granger Cause OP & 0.53805 & 1.01386 \\
OP does not Granger Cause RGDP & 0.04815 & 6.13267 \\
UNE does not Granger Cause OP & 0.83466 & 0.47945 \\
OP does not Granger Cause UNE & 0.11990 & 3.50134 \\
INF does not Granger Cause OP & 0.66689 & 0.75655 \\
OP does not Granger Cause INF & 0.85175 & 0.45194 \\
REER does not Granger Cause OP & 0.04241 & 6.60121 \\
OP does not Granger Cause REER & 0.61928 & 0.84474 \\
M does not Granger Cause OP & 0.91190 & 0.35027 \\
OP does not Granger Cause M & 0.16329 & 2.84424 \\
\hline
\end{tabular}

Source: prepared by the researcher - output software Eviews

Pair wise Granger Causality tests were conducted. The results are presented in table 3. At $5 \%$ significance level there are evidences that OP granger caused RGDP; REER granger caused OP; Other granger causalities between oil price and other macroeconomic variables are not statistically significant.

\subsection{Vector Error Correction Model Test}

The estimation and analysis of the model involves multi-stage procedure. The study first considered the correlogram for autocorrelation and. with the autocorrelations dying out and only the first partial correlation coefficient being significant. Based on the Johansen cointegration results and the results from the lag selection criterion; a VECM (2) with three cointegrating vector is estimated. To ensure that the estimated VECM is not spurious; the residual autocorrelation test is performed.

The correlograms of the test in figure 3 indicate that the residuals of the estimated VECM are appropriately uncorrelated; indicating that the estimated VECM is correctly specified and the parameter estimates are consistent.

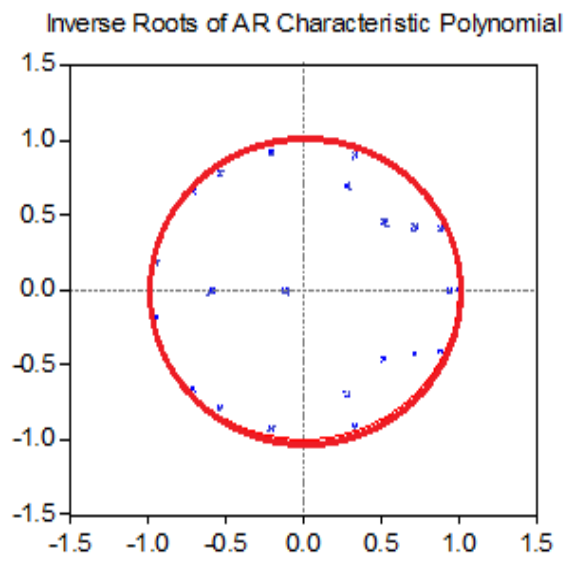

Figure 3. Stationary of the residuals

Source: prepared by the researcher - output software Eviews 
Figure (3) show that the model meets the conditions of stability as all parameters smaller than one; and all the roots lie within the unit circle; which means that the model does not suffer from the problem of autocorrelation or heteroscedasticity; which would allow step subsequent using vector error correction model VECM; which will allow us to track the relationship between the variables and as well as deviations that may occur in the short run.

Table 4. Vector error correction model

\begin{tabular}{|c|c|c|c|c|c|c|}
\hline Error Correction & $\mathrm{D}(\mathrm{OP})$ & $\mathrm{D}(\mathrm{Y})$ & $\mathrm{D}(\mathrm{UNE})$ & D(INF) & D(REER) & $\mathrm{D}(\mathrm{M})$ \\
\hline \multirow{3}{*}{ ECT 1} & -0.110526 & 0.029832 & -0.136106 & 0.716978 & 0.272820 & 0.155770 \\
\hline & $(0.19545)$ & $(0.01911)$ & $(0.03986)$ & $(0.40260)$ & $(0.06992)$ & $(0.05164)$ \\
\hline & {$[-0.56550]$} & [ 1.56080$]$ & {$[-3.41475]$} & [ 1.78089] & [ 3.90204] & [3.01625] \\
\hline \multirow{4}{*}{ ECT 2} & 1.216673 & -0.122439 & -2.392550 & -6.331991 & -0.248511 & -0.322202 \\
\hline & (1.68010) & $(0.16430)$ & $(0.34263)$ & $(3.46077)$ & $(0.60102)$ & $(0.44394)$ \\
\hline & [ 0.72417] & {$[-0.74522]$} & {$[-6.98296]$} & {$[-1.82965]$} & {$[-0.41348]$} & {$[-0.72579]$} \\
\hline & 0.004440 & -0.008028 & -0.492239 & 0.146596 & -0.003866 & 0.066302 \\
\hline \multirow[t]{2}{*}{ ECT 3} & $(0.33155)$ & $(0.03242)$ & $(0.06761)$ & $(0.68294)$ & $(0.11860)$ & $(0.08761)$ \\
\hline & [ 0.01339] & {$[-0.24761]$} & {$[-7.28019]$} & [0.21465] & {$[-0.03260]$} & [ 0.75683$]$ \\
\hline \multirow{4}{*}{$\mathrm{D}(\mathrm{OP}(-2))$} & -0.483964 & 0.007781 & -0.023825 & 1.963692 & -0.315293 & 0.035829 \\
\hline & $(0.25883)$ & $(0.02531)$ & $(0.05278)$ & $(0.53314)$ & $(0.09259)$ & $(0.06839)$ \\
\hline & {$[-1.86985]$} & [ 0.30742] & {$[-0.45138]$} & [ 3.68324] & {$[-3.40530]$} & [ 0.52389$]$ \\
\hline & -0.504494 & -0.024127 & 0.104998 & 0.122578 & -0.159873 & 0.065194 \\
\hline \multirow[t]{2}{*}{$\mathrm{D}(\mathrm{OP}(-3))$} & $(0.27967)$ & $(0.02735)$ & $(0.05703)$ & $(0.57607)$ & $(0.10004)$ & $(0.07390)$ \\
\hline & {$[-1.80391]$} & {$[-0.88220]$} & [ 1.84100$]$ & [ 0.21278$]$ & {$[-1.59803]$} & [ 0.88223$]$ \\
\hline \multirow{3}{*}{$\mathrm{D}(\mathrm{Y}(-2))$} & -0.196287 & -0.171607 & 1.089958 & -20.42256 & 1.795543 & -0.654671 \\
\hline & $(2.40122)$ & $(0.23482)$ & $(0.48969)$ & (4.94617) & $(0.85898)$ & $(0.63448)$ \\
\hline & {$[-0.08174]$} & {$[-0.73081]$} & [ 2.22583] & [-4.12897] & [ 2.09032] & [-1.03183] \\
\hline \multirow{3}{*}{$\mathrm{D}(\mathrm{Y}(-3))$} & -2.547089 & 0.083088 & 0.306641 & -0.056431 & 3.864697 & 0.525136 \\
\hline & $(2.57593)$ & $(0.25190)$ & $(0.52532)$ & $(5.30604)$ & $(0.92148)$ & $(0.68064)$ \\
\hline & {$[-0.98880]$} & [ 0.32984] & [ 0.58373] & {$[-0.01064]$} & [ 4.19401] & [ 0.77153$]$ \\
\hline \multirow{3}{*}{$\mathrm{D}(\mathrm{UNE}(-2))$} & -3.073039 & -0.131867 & 0.510683 & 0.435144 & 0.219423 & -0.080208 \\
\hline & $(0.68083)$ & $(0.06658)$ & $(0.13884)$ & $(1.40241)$ & $(0.24355)$ & $(0.17990)$ \\
\hline & {$[-4.51368]$} & {$[-1.98062]$} & [ 3.67814] & [ 0.31028$]$ & [ 0.90093$]$ & {$[-0.44586]$} \\
\hline \multirow{3}{*}{$\mathrm{D}(\mathrm{UNE}(-3))$} & 1.197260 & 0.137241 & -0.220992 & -3.247573 & 0.637097 & 0.340911 \\
\hline & $(0.76679)$ & $(0.07499)$ & $(0.15637)$ & (1.57948) & $(0.27430)$ & $(0.20261)$ \\
\hline & [ 1.56139] & [ 1.83024$]$ & {$[-1.41323]$} & {$[-2.05611]$} & [2.32261] & [ 1.68260$]$ \\
\hline \multirow{3}{*}{$\mathrm{D}(\mathrm{INF}(-2))$} & -0.263065 & -0.010517 & 0.013420 & 1.060076 & -0.079156 & 0.020554 \\
\hline & $(0.09002)$ & $(0.00880)$ & $(0.01836)$ & $(0.18542)$ & $(0.03220)$ & $(0.02378)$ \\
\hline & {$[-2.92245]$} & [-1.19477] & {$[0.73105]$} & [ 5.71721] & {$[-2.45819]$} & [ 0.86415$]$ \\
\hline \multirow{3}{*}{$\mathrm{D}(\mathrm{INF}(-3))$} & -0.184635 & 0.000313 & -0.025597 & 0.640822 & -0.014417 & 0.026552 \\
\hline & $(0.09151)$ & $(0.00895)$ & $(0.01866)$ & $(0.18850)$ & $(0.03274)$ & $(0.02418)$ \\
\hline & {$[-2.01760]$} & [ 0.03493$]$ & {$[-1.37161]$} & [ 3.39954] & {$[-0.44040]$} & [ 1.09808$]$ \\
\hline \multirow{3}{*}{ D(REER(-2)) } & -0.370039 & 0.027368 & 0.025278 & 1.373640 & -0.422461 & 0.040467 \\
\hline & $(0.44104)$ & $(0.04313)$ & $(0.08994)$ & $(0.90849)$ & $(0.15777)$ & $(0.11654)$ \\
\hline & {$[-0.83901]$} & {$[0.63454]$} & [ 0.28104$]$ & [ 1.51201$]$ & {$[-2.67764]$} & [ 0.34725$]$ \\
\hline
\end{tabular}




\begin{tabular}{ccccccc}
\hline & 0.594981 & 0.103737 & -0.030691 & -1.187947 & 0.367560 & -0.083364 \\
$\mathrm{D}(\mathrm{REER}(-3))$ & $(0.39478)$ & $(0.03861)$ & $(0.08051)$ & $(0.81320)$ & $(0.14123)$ & $(0.10431)$ \\
& {$[1.50710]$} & {$[2.68703]$} & {$[-0.38121]$} & {$[-1.46083]$} & {$[2.60265]$} & {$[-0.79916]$} \\
& 1.648967 & 0.141641 & -0.518131 & -4.639764 & 1.284818 & -0.364372 \\
$\mathrm{D}(\mathrm{M}(-2))$ & $(0.90322)$ & $(0.08833)$ & $(0.18420)$ & $(1.86050)$ & $(0.32311)$ & $(0.23866)$ \\
& {$[1.82566]$} & {$[1.60360]$} & {$[-2.81294]$} & {$[-2.49383]$} & {$[3.97646]$} & {$[-1.52675]$} \\
& 0.609631 & 0.008466 & -0.157312 & 0.147893 & -0.616950 & -0.293179 \\
$\mathrm{D}(\mathrm{M}(-3))$ & $(0.82979)$ & $(0.08115)$ & $(0.16922)$ & $(1.70925)$ & $(0.29684)$ & $(0.21926)$ \\
& {$[0.73468]$} & {$[0.10433]$} & {$[-0.92962]$} & {$[0.08653]$} & {$[-2.07840]$} & {$[-1.33715]$} \\
$\mathrm{C}$ & -0.125441 & 0.004750 & 0.022586 & 0.542903 & -0.126445 & 0.106933 \\
& $(0.08979)$ & $(0.00878)$ & $(0.01831)$ & $(0.18496)$ & $(0.03212)$ & $(0.02373)$ \\
$\mathrm{R}-$-squared & {$[-1.39700]$} & {$[0.54095]$} & {$[1.23341]$} & {$[2.93522]$} & {$[-3.93644]$} & {$[4.50695]$} \\
Adj. R-squared & 0.720239 & 0.696952 & 0.900712 & 0.862533 & 0.832473 & 0.708202 \\
F-statistic & 0.370538 & 0.318142 & 0.776603 & 0.690700 & 0.623064 & 0.343455 \\
Log likelihood & 2.059583 & 1.839845 & 7.257398 & 5.019592 & 3.975341 & 1.941626 \\
Akaike AIC & 37.05096 & 102.1487 & 81.57004 & 16.81716 & 65.83452 & 74.31699 \\
Schwarz SC & -1.503640 & -6.153482 & -4.683574 & -0.058369 & -3.559609 & -4.165499 \\
\hline
\end{tabular}

Source: prepared by the researcher - output software Eviews

As with most macroeconomic variables; all the six variables of the model are non-stationary at levels; Both Augmented Dickey- Fuller (ADF) and Phillips - Perron unit root tests are conducted. The two tests show similar Results; that all the variables are integrated at the first difference. As a matter of necessity; the study tested for cointegration using the Johansen approach which is suitable for VEC model. The result shows that (at 5\%) there is at least three cointegrating relation in each of the models. This naturally allowed us to proceed to the estimation of VECM.

The results of the VECM estimates are shown in table 4. The result of RGDP equation showed insignificant relationship between RGDP and second and third lag of OP. There is also significant but negative relation between RGDP and second lag of INF and UNE, and positive relation between RGDP and second lag and third lag of REER. The coefficients of the error correction terms in the RGDP equation are significant and negative; this confirmed the existence of a long-run static relationship in the model; and the value of coefficient of error correction (-0.12) indicates that(RGDP) adjusts to equilibrium value in each period by the imbalance remainder of the period (t-1) equivalent to $12 \%$. The $\mathrm{R}^{2}$ shows the model of this equation explains about $69 \%$ variations in RGDP.

In UNE equation the coefficients of second and third lags OP not significant; only the coefficients of second lags of RGDP and M2 are significant while others are not. The coefficients of the error correction terms in the UNE equation are significant and negative; this confirmed the existence of a long-run static relationship in the model; and the value of coefficient of error correction (-2.39) indicates that the Unemployment adjusts to equilibrium value in each period by the imbalance remainder of the period ( $\mathrm{t}-1)$ equivalent to $239 \%$. The $\mathrm{R}^{2}$ shows the model of this equation explains about $90 \%$ variations in UNE.

In INF equation the coefficients of the second lag of OP is significant and positive; and this consist with the economic theory; There is also Significant and negative relationship between INF and second lag of RGDP and UNE; and positive relation between INF and second lag and third lag of REER and M2 respectively. The coefficients of the error correction terms in the INF equation are significant and negative; this confirmed the existence of a long-run static relationship in the model, and the value of coefficient of error correction (-6.33) indicates that inflation adjusts to equilibrium value in each period by the imbalance remainder of the period (t-1) equivalent to $633 \%$. The $\mathrm{R}^{2}$ shows the model of this equation explains about $86 \%$ variations in INF.

In REER equation the coefficients of both second and third lags of OP are significant and negative; the coefficients of the third lag of RGDP and UNE significant and positive. However; both of second and third lag of INF and M2 respectively significant and negative; The coefficients of the error correction terms in the REER 
equation are significant and negative; this confirmed the existence of a long-run static relationship in the model; and the value of coefficient of error correction $(-0.24)$ indicates that real effective rate adjusts to equilibrium value in each period by the imbalance remainder of the period (t-1) equivalent to $24 \%$. The $\mathrm{R}^{2}$ shows the model of this equation explains about $83 \%$ variations in REER.

In M2 equation the coefficient of both second and third lags of OP are not significant; The coefficients of the third lag of RGDP and UNE significant and positive. However; both of REER and INF not significant; The coefficients of the error correction terms in the M2 equation are significant and negative; this confirmed the existence of a long-run static relationship in the model; and the value of coefficient of error correction (-0.32) indicates that money supply adjusts to equilibrium value in each period by the imbalance remainder of the period ( $\mathrm{t}-1)$ equivalent to $32 \%$. The $\mathrm{R}^{2}$ shows the model of this equation explains about $71 \%$ variations in $\mathrm{M} 2$.

The coefficients from the estimated VECM are not of primary interest in this empirical work. Rather; we focus on the impulse response function (IRFs) and variance decomposition (VDC) generated from the VECM.

\subsection{Variance Decomposition Results}

Variance decomposition shows the proportion of the forecast error variance of a variable that is attributable to its own innovations and other variables. Since we are primarily interested in how different macroeconomic variables respond to oil price shocks; the results presented in Table 5 show the variance decompositions for different variables attributable to oil shocks.

The result of VD in table 5; presented that the largest source of shocks was changes in OP itself; which contributed about $100 \%$ in $1^{\text {st }}$ year declining to $78 \%$ in tenth year.

Table 5. Variance decomposition

\begin{tabular}{llcccccc}
\hline Dependent variable & Period & OP & RGDP & UNE & INF & REER & M2 \\
\hline \multirow{2}{*}{ OP } & 1 & 100.0000 & 0.000000 & 0.000000 & 0.000000 & 0.000000 & 0.000000 \\
& 5 & 79.73126 & 13.19901 & 1.832299 & 2.688047 & 2.371156 & 0.178231 \\
RGDP & 10 & 78.28494 & 13.52352 & 2.383978 & 2.752426 & 2.934969 & 0.120167 \\
& 1 & 0.016948 & 99.98305 & 0.000000 & 0.000000 & 0.000000 & 0.000000 \\
& 5 & 36.43219 & 57.99504 & 0.084486 & 0.973413 & 4.298206 & 0.216669 \\
UNE & 10 & 49.03873 & 41.41597 & 0.800220 & 1.116801 & 7.431016 & 0.197256 \\
& 1 & 2.314665 & 69.96534 & 27.72000 & 0.000000 & 0.000000 & 0.000000 \\
& 5 & 22.16260 & 74.35221 & 2.330132 & 0.219297 & 0.899458 & 0.036302 \\
INF & 10 & 38.12257 & 58.65191 & 0.733840 & 0.225313 & 2.239808 & 0.026552 \\
& 1 & 0.109357 & 12.07466 & 20.83295 & 66.98303 & 0.000000 & 0.000000 \\
& 5 & 19.68770 & 25.90242 & 7.628438 & 41.44879 & 5.017239 & 0.315415 \\
REER & 10 & 18.13445 & 31.08017 & 6.530722 & 37.80986 & 6.163323 & 0.281474 \\
& 1 & 12.90062 & 0.085446 & 4.121962 & 3.010293 & 79.88168 & 0.000000 \\
& 5 & 64.23630 & 2.352766 & 4.609518 & 8.131311 & 20.20491 & 0.465199 \\
M2 & 10 & 80.12920 & 3.175941 & 3.223880 & 4.623392 & 8.605386 & 0.242201 \\
& 1 & 61.66287 & 6.635158 & 16.89754 & 0.403647 & 11.29482 & 3.105957 \\
& 5 & 64.04802 & 10.40810 & 4.005226 & 6.877562 & 13.48014 & 1.180951 \\
& 10 & 62.81239 & 8.339034 & 4.732377 & 7.382286 & 15.50603 & 1.227884 \\
\hline
\end{tabular}

Source: prepared by the researcher - output software Eviews

\subsubsection{RGDP}

For RGDP; the largest source of shocks was changes in RGDP itself; which contributed about 99.98percent in the first year; declining to about 41.41 percent in the last year. The contribution of oil price shock to real GDP violability was about 0.0169 percent in the first year; rising to about 39.40311 percent in six year and about 
49.03873percent in the $10^{\text {th }}$ year. The implication of this finding is that oil price shock does significantly affect RGDP in Algeria in the long-run more than the short-run. But the contribution of oil prices in RGDP are not very high and that reinforces the fact that oil price shocks are neither necessary nor sufficient to explain changes are happen in RGDP (Kilian 2004; Philip 2008).

\subsubsection{Unemployment}

RGDP changes accounts for the largest share of shock to Unemployment rate; while oil price shock explained relatively little in short-run. RGDP changes contributed about 69.96 percent to Unemployment rate in the first year; declining through 58.65 percent in the tenth year. And after that we fine Unemployment rate contributed about 27.72 percent to changes in itself in the first year; declining through 0.73 percent in tenth year. However; oil price explained only 2.31 percent of changes in Unemployment rate in the first year; rising to about 38.12 percent in the tenth year. This finding confirms that oil price may not be necessarily unemployment contrary to findings by Gunu (2010).

\subsubsection{Inflation}

The largest source of shocks in inflation was changes in inflation itself; which contributed about 66.98 percent in the first year; declining to about 37.38 percent in the last year, after that the UNE changes accounts for the largest share of shock to inflation rate; while oil price shock explained relatively little. UNE changes contributed about 20.83 percent to changes in commodity price level in the first year; declining through 6.53 percent in the tenth year; and that consist with Keynesian approach. However; oil price explained only 0.11 percent to changes in inflation rate in the first year; rising through 21.38 percent in the third year and declining through 18.13percent in the tenth year. This finding confirms that oil price may not be necessarily inflationary contrary to findings by (Al-mulali \& Usama 2011); and consist with some studies (Philip 2008; katsuya 2008).

\subsubsection{The Real Exchange Rate}

The variance decompositions evidenced in Table 5 suggests that the largest source of shocks was changes in REER itself; which contributed about 79.88 percent in the first year; declining to about 8.6 percent in the last year; shocks to oil price explained about 12.9 percent of shocks to the real exchange rate in the 1st year rising in effects to about 80.12 percent in tenth quarter; The implication of this finding is that oil price shock does significantly affect REER in Algeria in the long-run more than the short-run. The contribution of M2 shocks do not contribute significantly to shocks in real exchange rates; as it was less than 1 percent over a ten-month period. Also; shocks to RGDP and INF contributed an average of 4 percent to real exchange rate shocks over from the period studied. This finding is consistent with previous studies that oil price shocks do significantly affect the real exchange rate (Akin \& Babajide; 2011, and leili 2010; Mohammad Reza 2009). Thus; a high real oil price may have given rise to wealth. This squeezed the tradable sector and gave rise to the "Dutch-Disease syndrome in Algeria.

\subsubsection{Money Supply}

Shocks to oil price contribute to the shocks in money supply in fixed amount. However; from the first year to the last; shocks to oil price contributed about average of 61 percent and 64 percent to changes in domestic money supply. On the other hand; while the other macroeconomic variables did not initially contribute much to the shocks in M2; in exception the REER which contribute 11 percent in $1^{\text {st }}$ year rising to 15.5 percent in the tenth year. An important finding here is that both oil price shocks and shocks to the real exchange rates affected domestic money supply at long lags. This supports earlier studies that monetary policy responds to oil price shocks.

\subsection{Impulse Response Function}

An impulse response function (IRF) traces the effects of a one-time shock to one of the innovations on current and future values of the endogenous variables. If the innovations $\varepsilon_{t}$ are contemporaneously uncorrelated; the interpretation of the impulse response is straightforward. The $i$ the innovation $\varepsilon_{\mathrm{i}, \mathrm{t}}$ is simply a shock to the $i$ the endogenous variable $\mathrm{y}_{\mathrm{i}, \mathrm{t}}$. contain the impulse response functions for the responses of the macroeconomic variables to different oil price shocks. Each figure traces the effect of a one-time shock to the measures of oil shocks on the current and future values of each of the macroeconomic variables. 


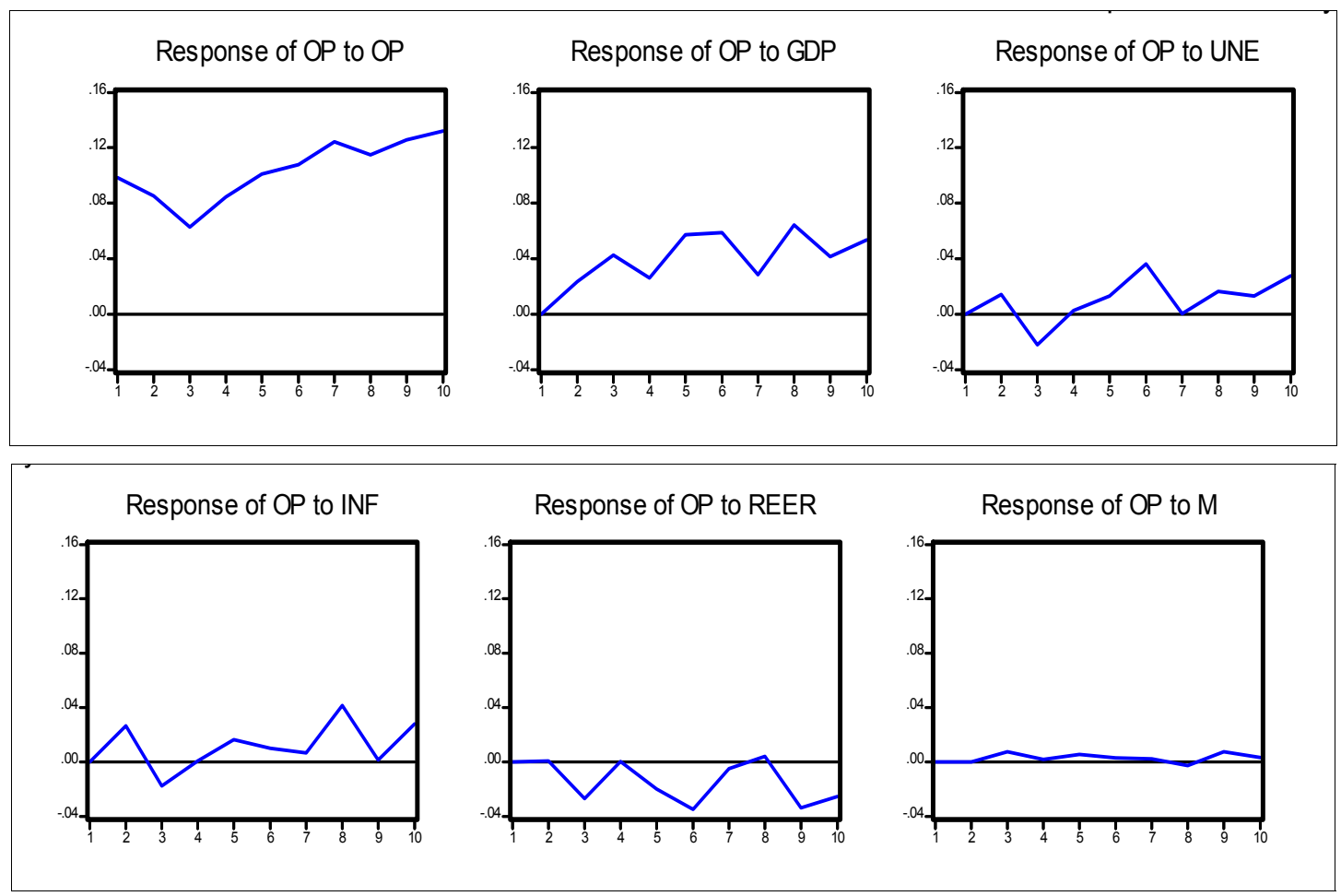

Figure 5. Impulse response function of inflation dynamics

Source: Prepared by the researcher - output software Eviews

Figure 5 Shows Impulse Response Function of macroeconomic variables (RGDP; UNE; INF; REER and M2) sudden change rate of one standard deviation in each of Oil prices shocks.

Is clear from Figure1 that the oil prices have a positive effect on RGDP and the effect lasts for the rest of years. So that any sudden $1 \%$ changes in the amount of OP and a standard deviation of a single positively affect RGDP; but this effect is not directly and appears after two years.

The response of unemployment, the result of IRF showed that the oil price affect the unemployment negatively; but the impact is indirect appears after three years, and the effect lasts for two years and then begins to recede; so any sudden change rate of a standard deviation of one affects negatively on unemployment rate and continues to this effect for a short period only.

As for the changing oil prices on inflation; the impact was positive start after the fourth year and fades in the long term so that any sudden change in oil prices amounting to one standard deviation and a positive impact in inflation; but this effect is not directly; appears after four years. As for oil prices shocks; the positive impact is little in the short term inflation appears after the fourth year; and was compatible with the results of previous tests, so that any sudden change in the oil prices shocks of standard deviation of one affects positively on inflation; but this effect is not directly but appear after four years.

The response of real effective exchange rate to shocks in oil prices is mixed. The fourth year and seventh show a positive response of REER to oil shocks. While; the impact was negative appears in the second year to the tenth year; so that any sudden change in the oil prices shocks of standard deviation of one affects negatively on REER; but this effect is not directly but appear after two years.

The response of money supply to shocks in oil prices is small and positive very limited; so that any sudden change rate of a standard deviation of OP affects positively on M2 and continues to this effect for a short period only for two years and then this becomes a non-significant effect after the third year.

\section{Discussion Result}

The results showed no significant effect to the fluctuations of oil prices on real GDP in the short term. However; the effect appears in the long term after the second year as the sudden change in oil prices of one dollar standard deviation of one affects positively on RGDP on the length of the response; and this result is consistent with many 
previous studies; but it is noted through the Impulse Response Function test can observe the decline in RGDP over the past two fourth and seventh year, and that can explained as indicated by the results of the reaction of the response function for both inflation and unemployment and the REER which has seen a rise this year; as these factors can be combined negative impact on RGDP.

The results showed no significant effect to the oil price fluctuations on the UNE in the short term. But that; through the VD and IRF Test showed that there is a negative impact appear in third year and this result; the fact that the impact of oil prices on unemployment appear in long-term, to lower unemployment rate take a time to create a new projects. The negative impact of oil prices on UNE disappears fast and returns short and to high unemployment rate; can explain that from the increasing trend of disinterest in highly labor-intensive works such as agriculture and factory work; and that's what can called Dutch disease.

Proved the results of the study the positive impact with a statically significant to the oil prices fluctuation on inflation INF in the short and long term; and this result is consistent with economic theory; where high oil prices lead to capital flows suddenly to the national economy on the one hand; the other hand the increase in real oil price significantly rise both RGDP per capita and CPI (inflation) for the first two years after the initial shock; this strong increase in GDP increase aggregate demand in the economy. and consequently; the general level of prices. In addition to the high price index a result of high consumer prices for imported products and is known as Imported Inflation.

The results showed a Negative significant effect of oil prices on the REER in the short and long term; the IRF of REER suggests that, in the short and long-run; this variablereacts to shock in real oil price by depreciation could be explained by the fact that rising oil prices lead directly to higher inflation in the major trading partners of Algeria via higher import prices; while domestic prices of energy products are highly subsidized in Algeria and are below global market prices; in addition to that; the reason is due to the exchange rate regime applied in Algeria; is the floating exchange rate orbit; which is characterized by a lesser degree of flexibility; as it seeks monetary authorities always to keep it close to the equilibrium value; which prevents the rise significantly; in order to achieve certain economic objectives.

The results showed no significant effect of oil price fluctuation on the expended Money supply M2 in the short and long term; and this is due to the monetary policy applied in Algeria; where the government will intervene to absorb excess liquidity in the national economy, as it seek the central bank and for a long time to keep inflation stable through intervention in determining the amount of money supply; in addition to the many factors that affect the expanded money supply like the deposits demand in national and foreign currencies with the banking system; and saving deposits...ect.

\section{Conclusion and Recommendation}

We have reached five main conclusions:

The oil prices fluctuations has an indirect positive effect on RGDP; that explain by the increase in oil prices caused a higher cash income; and this will affect all the components of GDP; with a high marginal propensity to consumer; so that encourage foreign investors to settle their investment in the country; and will increase government spending and all this in the latter will lead to improvement in real GDP.

the dependence of the oil sector in Algeria increase since more than four decades has led to the; that led to the deterioration of many of big industries as an industry of iron; and the textile industry and leather; which was contribute significantly over the previous period to the absorption of unemployment and this known as the impact of Dutch Disease.

Increasing oil prices lead to higher costs in industry in developed countries, and the fact that Algeria; like other developing oil-producing countries, the persistence of high oil prices lead to higher domestic demand for import and therefore higher inflation resulting from imported inflation.

The exchange rate regime in Algeria (the floating exchange rate); led to emergence of a negative impact of oil prices on the real effective exchange rate; in addition to Algerian exports of oil in U.S dollar and id considered one of the most important importers from the European Union; so most of its imports are in euro and this is what causes the negative impact of oil price on the real effective exchange rate.

The Algerian Central Bank pursuing a tight monetary policy which aim to control the volume of liquidity in the national economy; and this led to the limited impact of oil prices on the money supply; and this is what led to concluded that inflation is happening in the Algerian economy is not the result of the high money supply.

Finally; through the results obtained by analysis of econometric model we can give some recommendation; 
which can be summarized in the following points:

- The development of non-oil export as a way of diversifying the productive base of Algeria; a country that is highly endowed with national resources; the economy is still far from being diversified.

- The researchers also recommend that the Algerian government uses its oil revenues and the financial surpluses to develop the other economic sectors in order to reduce its dependency on the petroleum sector. And to induce the aggregate demand to absorb the unemployment by product investment; and reduce the inflationary pressures.

- Use a basket of currencies to do their foreign trading transaction; so as to avoid losses resulting from the depreciation of the dollar; and diversification of sources of imported goods; especially from the regions of dollar because it will be less expensive than the imported from euro region; must applied of more flexible exchange rates to achieve a real independence of the monetary authorities for help to face external shocks.

\section{References}

Abdusalam F. Y., \& Ali Salman Saleh. (2008). Economic Sanctions, Oil Price Fluctuations and Employment: New Empirical Evidence from Libya. American Journal of Applied Sciences, 5(12), 1713-1719. http://dx.doi.org/10.3844/ajassp.2008.1713.1719

Agnes Bénassy Q., Valeria. M, A. (2005). China and Relationship Between The Oil Price and The Dollard. CEPII: Centred etude prospective et d information International, 16.

AkinIwayem, B. Fowowe. (2011). Impact of Oil Price Shocks on Selected Macroeconomic Variables in Nigeria. International Elsevier Science: Energy Policy, 39, 603-612.

Aliyu, ShehuU. Rano. (2009). Oil Price Shocks and the Macroeconomic of Negeria: A Non Linear Approach. Munich Personal RePEc Archive: MPRA, 18726, 1-36.

Al-mulali. U, Che Sab., \& CheNormee. (2011). The Impact of Oil Shocks on Qatar's GDP. Munich Personal RePEc Archive: MPRA, 27822, 1-24.

Bouguerra. R., \& Ouada. R. (2011). The Use of Econometrics Modeling in the Study and Measurement of the Demand for Money: the Algerian Case. Science Journal of Economics, 1-16.

Chennai. (2009). Impact of High Oil Prices on African Economy.African Development Bank, 2(123), 233.

Christopher A. Sims. (1980). Macroeconomics and Reality. Economitrica, 48(1), 1-48. http://dx.doi.org/10.2307/1912017

Chuk. A. C., Ekpeno L. E., \& Ndifreke R. S. (2010). Oil Price distortion and their Short and Long-Run Impact on Nigerian Economy. Munich Personal RePEc Archive: MPRA, 2443, 15.

Cooper, John C. B. (2003). Price Elasticity of Demand for Crude Oil: Estimates for 23 Countries. OPEC Review, 27(1), 1-8. http://dx.doi.org/10.1111/1468-0076.00121

Dahl, Carol A. (1993). A Survey of Oil Demand Elasticities for Developing Countries. OPEC Review, 17, 399-419. http://dx.doi.org/10.1111/j.1468-0076.1993.tb00484.x

Francois L., \& Valérie Mignon. (2008). On the Impact of Oil Prices on Economic Activity and Other Macroeconomic and financial Variables. CEPPI: Centre D`etudes Prospective et d'InformationInternational Working Paper, 05.

Günsel Dğrul, H., \& Ugur S. (2010). Relation between Oil Price, Interest Rate, and Unemployment: Evidence from Emerging Market. ELSEVIER: Energy Economy, 32, 1523-1528.

Gunther Markwardt. (2010). The impact of oil price volatility on the macro economy in Russia. The Annals of Regional Science, 48(3), 695-702.

Gunu Umar., \& Kilishi, A. A. (2010). Oil prices and the terms of trade. International Journal of Business and Management, 5(8), 39-49.

Ibrahim Al-Ezzee. (2011). Real Influences of Real Exchange Rate and Oil Price Changes on the Growth of Real GDP: Case of Bahrain. International Conference on Management and Service Science, IPEDR, 08, 155-164.

Jabavu C. Nkomo. (2010). Crude oil price hikes and issues for energy security for southern Africa. Journal of Energy in Southern Africa, 21(2), 12-16. 
James D. Hamilton. (2003). What is an Oil Shock?. Journal of Econometrics, 113, 363-398. http://dx.doi.org/10.1016/S0304-4076(02)00207-5

James D. Hamilton. (2005). Oil and the Macroeconomy. Retrieved from http://dss.ucsd.edu/ jjhamilto/JDH_palgrave_oil.pdf

James D. Hamilton. (2009). Causes and Consequences of the Oil Chock of 2007-2008. Broking Papers on economic activity, spring, 215-261.

James D. Hamilton., \& Ana Maria Herrera. (2004). Oil Shocks and Aggregate Macroeconomic Behavior: The Role of Monetary Policy. Journal of Money, Credit, and Banking, 36, 265-286. http://dx.doi.org/10.1353/mcb.2004.0012

Jiménez-Rodríguez R., \& Marcelo S. (2004). Oil price shocksand real GDP growth: Empirical evidence for some oecdcountries. Working paper series European Central Bank, 362.

Katsuya Ito. (2008). Oil Price and the Russian Economy: A VEC Model Approach. International Research Journal of Finance and Economics, 17, 68-74.

Katsuya Ito. (2010). The impact of oil price volatility on the macro economy in Russia. Springer-Verlag, Economic Analysis Working Papers, 9(5), 1-8.

Leili Nikbakht. (2010). Oil Prices and Exchange Rates: The Case of OPEC. Business Intelligence Journal, 3(1), 83-92.

Lutiz Kilian, Alessandro Rebucci., \& Nikola Spatafora. (2007). Oil Shock and External Balance. Journal of International Economics, 77(2), 181-194. http://dx.doi.org/10.1016/j.jinteco.2009.01.001

Lutiz Kilian. (2010). Oil Price Volatilit: Origins and Effect. World Trade Organization: Economic Research and Statistics Division, 2.

Michael Leblanc., \& Menzie D. C. (2004). Do High Oil Prices Persage Inflation? The Evidence from G-5 Countries. SCCIE: Santa Cruz Center for International Economics, 4.

Michael Strum, François G., \& Juan Gonzalez A. (2009). Fiscal Policy Challenges in Oil Exporting Countries: A Review of Key Issus. European central Bank Occasional paper series, 1041.

Mohammad Reza F., \& Gunther M. (2009). The effects of oil price shocks on the Iranian economy. International Elsevier Science: Energy Economics, 31, 134-151.

Nkomo J. C. (2006). The Impact of Higher Oil Prices on Southern African countries. Jornal of Energy in Southern Africa, 17, 1.

Philip A. O. (2006). Oil Price Shock and Macroeconomic Activities in Nigeria. International Research Journal of Finance and Economics, 3, 28-34.

Stephen P. A., Brown, M. K., \& Yu C. (2002). Energy prices and aggregate economic activity: An interpretative survey. The Quarterly Review of Economics and Finance, 42, 193-208. http://dx.doi.org/10.1016/S1062-9769(02)00138-2

Sulaiman D. Mohammad. (2010). The Impact of Oil Prices Volatility on Export Earning in Pakistan. European Journal of Scientific Research, 41(4), 543-550.

Syrous K. K., Ayser Phillip S., \& Marjorie S. (2006). The Impact of Oil Prices on Employment. International Research Journal of Finance and Economics, 5, 136-154.

Wakeford, J. J. (2006). The Impact of Oil Prices Shocks on the Southern African Macroeconomy, History and Prospect. SARB Conference, 18-20. 